\title{
The Performance of Compliant Stocks during the COVID-19 Crisis
}

\author{
Amel Farhat ${ }^{1}$ and Amal Hili ${ }^{2}$ \\ ${ }^{1}$ Business School, University of Sherbrooke, Canada \\ ${ }^{2}$ ISG-University of Sousse, University of Carthage, ESSAI, L.R. MASE (LR21ES21), Tunisia
}

\begin{abstract}
The outbreak of the COVID-19 pandemic and the associated lockdowns across the world led to a sharp decline in the market value of the global equity markets. The purpose of this paper is to answer the following question: Do Compliant firms outperform the Non-Compliant during the COVID-19 pandemic? A compliant firm must satisfy the qualitative and quantitative criteria defined by Islamic law. Previous research focused on the performance of Compliant mutual funds, banks, and market indexes. Our paper stands out by sorting the cross-section of individual firms into Compliant and Non-Compliant firms and by analyzing the stock performance of each group during the COVID19 crisis. Our empirical investigation is twofold: First, it includes quarterly cross-sectional regressions during the first two quarters of 2020. We show that the effect of firms' compliance on abnormal returns is positive and significant during both quarters. Second, it uses difference-in-difference regressions of daily abnormal returns and volatility on the interaction between the Compliant dummy variable and Post-COVID dummy which equals 1 during the crisis period (February 24th to April 17th) and zero otherwise. We find that Compliant stocks outperform the non-Compliant peers during the pandemic. We highlight that this out-performance is not associated with higher firm-specific or total risk.
\end{abstract}

Keywords: Islamic finance, stock return, total risk, firm-specific risk, covid-19 


\section{Introduction}

The outbreak of the COVID-19 pandemic and the associated lockdowns across the world led to asharp decline in the market value of the global equity markets. The global market levels reached alow record in mid-March 2020, not observed since the Global Financial Crisis (GFC). The purpose of this paper is to answer the following question: Do Compliant firms outperform their Non- Compliant peers during the COVID-19 pandemic?

A Compliant firm must satisfy the qualitative and quantitative criteria defined by Islamic law. Previous research concentrates mainly on Compliant mutual funds, banks, and stock market indexes and proves that Islamic finance is more resilient during the GFC compared to conventional finance. The Islamic finance resilience can be explained by its risk-bearing nature as it excludes high risk profile companies through a detailed screening process; see for example (Kayed \& Hassan, 2011; Hasan \& Dridi, 2011); Altarawneh \& Lucas (2012); Bitar et al., 2017). Our paper compliments the previous faith-based empirical finance literature and stands out by grouping the cross-section of individual firms into Compliant and Non-Compliant firms according to the Islamic law and by analyzing the stock performance of both groups during the COVID-19 crisis. To our knowledge, there is no research paper conducted to sort the cross-section of stocks into Compliant and Non-Compliant groups based on the qualitative and quantitative criteria defined by the Islamic law and to investigate the resilience and performance of individual Compliant companies compared to their conventional peers during a period of crisis.

The screening methodology we use is strict. We implement a two-step screening process with two types of screening criteria: qualitative criteria related to business categories and quantitative criteria related to financial ratios. This allows us to create the Compliment dummy variable which equals to one if the firm satisfy the screening criteria and zero otherwise. Starting from 2274 firms during the first quarter of 2020, only 672 firms are Compliant. As shown in Table 2, Compliant firms in our sample, exhibit low leverage and high growth and investment opportunities.

Despite this thorough screening process, the COVID-19 pandemic exposes, both conventional and Compliant stocks, to the same financial and economic shock as the pandemic led to the shutting down of huge parts of the economy. The question is whether Compliant individual companies would exhibit more resilience during the pandemic than their conventional counterparts.

Our empirical investigation is twofold: First, it includes quarterly cross-sectional regressions during the first two quarters of 2020. We show that the effect of firms' compliance on abnormal returns is positive and significant at $0.1 \%$ level (respectively 5\% level) during the first quarter (respectively the second quarter) with and without including the control variables. Note that the effect is less pronounced during the second quarter. This decline in the impact of the compliance status on stock return can be explained by the major government actions to support the economy and the financial system during the second quarter of 2020. We also provide evidence that the outperformance of Compliant stock returns during the pandemic is not explained by a higher risk. Indeed, the effect of the compliance status on firm-specific and total volatility is significantly negative at $0.1 \%$ level. Second, it uses difference-in-difference regressions of daily abnormal returns and volatility on the interaction between Post $C O V I D$, and Compliant dummy variable. This allows to discern the effect of compliance on the firm financial performance during the COVID-19 crisis. The COVID-19 crisis 
is represented by the period between February 24th, 2020 to April 17th,2020. Thus, Post Covid $t$ equals 1 during the crisis period and zero otherwise. We find that Compliant stocks perform better during the pandemic and that this out-performance is not associated with higher risk as Compliant stocks are evidenced to be less volatile than their non-Compliant peers during the COVID-19 period.

The remainder of this paper is organized as follows: Section 2 provides a review of the finance literature dealing with Islamic finance resilience under economic turmoil. Section 3 describes the data along with the screening methodology to be used. Section 4 presents the descriptive statistics along with the empirical methodology and findings. The last section concludes.

\section{Literature review}

Our paper is related to several articles and the closest stream of literature to ours is the one dealing with the impact of covid19 on Islamic Financial Services Industry (IFSI) including three main entities: funds, banks, and capital markets. To the best of our knowledge, few articles have dealt with this current hot topic and most of them compare the resilience and performance of the three different components of the IFSI to their conventional peers.

(Yarovaya et al. , 2020) show that Islamic equity funds exhibit more resilience to the COVID19 shock and outperform their conventional counterparts during the pandemic. (Hassan et al., 2020) present the role of Islamic banking system and the new technological innovation (also known as Fintech) in creating a more sustainable environment COVID-19 crisis. (Sherif, 2020) investigates the impact of COVID-19 on the performance of the Dow Jones Islamic market index (DJIS) compared to its UK counterpart and finds evidenceof a negative relationship between the COVID-19 pandemic and the DJIS. (Ashraf et al., 2020) question whether indices following Islamic investment principles provide hedging benefits to the investors during the COVID-19 pandemic compared to the PreCOVID-19 period for global, US, and European markets. The authors prove that during market downfalls, Islamic equity indices do not lose as much as their conventional peers and that this outperformance comes with higher systematic risk. (Erdoğan et al., 2020) show that Islamic stock market indices are more stable to the pandemic shock than the conventional peers in Turkey. (Salisu \& Sikiru, 2020) provide evidence of the hedging effectiveness during the COVID-19 pandemic of the DJIS Asia/Pacific index compared to the Standard and Poor Dow Jones Composite Average stockindex and find higher stock returns and lower volatility of Islamic stocks Indexes relative to their counterparts during the pandemic.

Indices complying with Islamic investment criteria are not the only indices that outperform during the pandemic. (Albuquerque et al., 2020) show that stocks with high Environmental and Social ratings exhibit significantly higher returns, lower volatilities, and greater trading volumes than other stocks during Covid-19 pandemic. (Acharya \& Steffen, 2020)and (Ramelli \& Wagner, 2020) prove that respectively firms with committed access to sources of liquidity and those with greater cash holdings and lower financial debt are less affected by the Covid-19 pandemic and the resulting stock market crash. Likewise, (Mnif et al., 2020) prove that Covid19 has a positive effect on the efficiency of the cryptocurrency market.

The Covid-19 pandemic is often compared to the GFC. It seems thus important to relate our paper to some of the literature investigating the out-performance of Islamic investments during the subprime crisis. To the best of our knowledge, (Tahir \& Ibrahim, 2020) is the only empirical study dealing with the out-performance of individual Compliant companies' returns compared to 
MUNICH, GERMANY

29-31 July, 2021

conventional companies rather than analyzing stock market indices performance during and after the financial collapse period,. The authors use a Database from the Financial Times Stock Exchange (FTSE) all world index to measure the individual companies' accounting and market returns during two periods of time: the financial recession of 2007-2010 and the post-recession years of 20112014. The model used is an ordinary least square regression and the main finding states thatCompliant companies outperform the Non-Compliant companies, in terms of both accounting andmarket returns during the recession period. This research is different from ours in many aspects. First, we construct our database by filtering companies selected from CRSP and Compustat-Capital IQ, using both quantitative and qualitative screening criteria. Second, the quantitative approach we use is more elaborate as we conduct a difference in difference estimation using abnormal daily re-turns. Third, we deal with the impact of the pandemic on Islamic companies returns rather than the subprime crisis and these two worldwide crises are different in terms of origins and consequences.

In contrast to (Tahir \& Ibrahim, 2020), most research is carried out on indices and focuses on the comparison between the performance of Islamic and conventional indices during the GFC. (AlKhazali et al., 2014) use stochastic dominance to show that nine DJIS indexes out- perform their conventional peers' indexes during the GFC. Milly \& Sultan (2012) compare the performance of investing in Islamic stocks and socially responsible stocks compared to conventional and find that Islamic stock investment generates significantly higher Sharpe ratios especially during the GFC. Arshad \& Rizvi (2013) prove that Islamic indices testify more stable during thesubprime crisis due to their rigid screening criteria. Dewandaru et al. (2014) focus on excessive contagion effects and provide evidence that Islamic stock markets are less affected by the GFC than their counterparts. Arouri et al. (2013) use the Morgan Stanley Capital International closing prices to show that Islamic indexes offer higher returns associated with lower volatility during global financial turmoil. Sukmana \& Kolid (2012), Miniaoui et al. (2015), and Abduh (2020) aim at investigating the volatility of conventional and Islamic indices during the GFC in respectively Indonesia, the Gulf Cooperation Council countries (GCC) and Malaysia using among others, GARCH model. Interestingly, Sukmana \& Kolid (2012) and Abduh (2020) show that Islamic index volatility is lowerduring the GFC whereas Miniaoui et al. (2015) prove that investing in Islamic stock index is not less risky than investing in conventional one. In the same vein, Hammoudeh et al. (2014) and Trabelsi et al. (2020) show that Islamic indices are also exposed to the GFC and do not exhibit a statistically significant difference in performance compared to their conventional peers.

Regarding the banking sector, (Bourkhis \& Nabi, 2013 and Hasan \& Dridi, 2011) show that Islamic banks exhibit more resilience to the subprime crisis than conventional banks. These findings are not in line with Amar et al. (2017) and Karim et al. (2012) who investigate the impact of the GFC on Islamic banks respectively in three GCC countries and Malaysia. Evidence is provided that Islamic banks in these countries are more vulnerable to the financial distress.

Merdad et al. (2010) focus rather on the risk-return profile and performance of Islamic and conventional mutual funds managed by HSBC in Saudi Arabia. Their risk-adjusted performance measures suggest that Islamic mutual funds outperform conventional ones during the GFC, offering thus hedging benefits to investors. Ahmad et al. (2020) examine the impact of the GFC on a Compliant capital protected fund called the Meezan Capital Protected Fund (MCPF) and find that unlike conventional equity funds, the MCPF generates a small positive return.

The question that arises is how individual returns of Compliant companies react to the current 
MUNICH, GERMANY

29-31 July, 2021

pandemic compared to non-Compliant companies.

\section{Data description}

This study includes firms listed in both the Center for Research in Securities Prices (CRSP) dailyfile and the Compustat - Capital IQ quarterly during the Covid-19 crisis. Returns data is obtained from CRSP and accounting data is obtained from Compustat. We include all stocks listed in New York Stock Exchange (NYSE), American Stock Exchange (AMEX) and The Nasdaq Stock Market with share code 10 or 11 (common stocks). In order to ensure that the illiquid stocks are not considered in our analysis, we exclude penny stocks (price below \$5) and micro-caps (stocks in the bottom 2 deciles of the monthly size distribution). We end up with a sample of 2274 firms.

Next, we categorize stocks into Compliant and Non-Compliant based on qualitative and quantitative criteria described in detail below.

\subsection{Screening Process}

Our screening methodology consists of using a two-step screening process with two different types of screening criteria: qualitative criteria related to business categories and quantitative criteria related to financial ratios. We start by screening firms according to their business activities and then further filter the remaining companies in accordance with their financial ratios.

\subsubsection{Qualitative criteria.}

Qualitative screening criteria are related to business activities. In all Shariah screening mainstreams, the first qualitative criterion consists of excluding companies whose main business activity is not permissible by Shariah. To that purpose, we use two filters: Security Industry Code (SIC) Filter and Business Description Keyword Filter.

Security Industry Code (SIC) Filter. Most of the researchers use Security Industry Codes (SICs) to identify companies within some specific industries. All companies with a financial activity orientation are excluded from the sample of Compliant companies using the Security Industry Code (SIC) Filter. Those financial companies are classified with SICs from 6000 to 6999. We start thus by removing them from the sample. Other companies with a non-financial activity orientationbut operating some business activities prohibited by Shariah need as well, to be removed from the sample of Compliant companies using the SIC description. We exclude companies if one of the following words appears on their SIC description (COMPUSTAT item sicdescr): wines; wine and; toba; animal spec; hogs; slaughtering; malt bev; liquor; cigarette; cigars; ammunition; small arms; ordnance; missiles; tanks; music; beer; investor; motion; picture; video; dance; theatrical; band; entertainment. 
Business Description Keyword Filter. According to this second filter, qualitative screening is made based on the business activity description. Six international Islamic indexes (Dow Jones Islamic Market Index, DJMI; Financial Times Stock Exchange, FTSE, Morgan Stanley Capital International Global Islamic Index, MSCI; Thomson Reuters Ideal Rating Islamic indices; the STOXX Europe Islamic Index and Standard and Poor's Shariah Index) along with many Shariah service providers as (Shariah Capital, SC; Al-Meezan and Azzad) provided a comprehensive list of Non- Compliant business activities. Ho et al. (2012) breakdowns those impermissible business activities into five classifications: Riba (interest in conventional banks) and Gharar (trading in uncertainty and risk), gambling and gaming, non-halal products, immoral and other impermissible activities. We use these lists to exclude in an exhaustive way all impermissible activities belonging to the five classifications. We remove thus every firm if one of the following words appears on the business description (COMPUSTAT item busdesc): adult; affiliate; album; alcohol; arms; artillery; assurance; attack; bacon; bank; beef; beer; betting; blackjack; bond; bourbon; brandy; brewery; broker; bullet; cabletv; carcass; casino; champagne; chicken; cigar; cigarette; cinema; cocktail; cognac; credit; disco; discount house; distiller; draught; duty free; entertainment; fighter jet; finance; future; gambling; gaming; gun; guns; ham; hellicopter; hock; hog; insurance; interest; investment; lager; landmines; lease; leasing; lender; lending; lessors; liqueur; liquor; loan; lottery; machine gun; meat; military; missile; mortar; music; nightclub; options; pig; playboy; poker; pork; port wine; poultry; quzuo; records; reinsurance; rifle; roulette; rum; salami; sausage; scotch; slot machine; spirit; supermarket; sweepstakes; swine; tank; tequila; tobacco; toto; vodka; war vessel; warthog; weapon; whiskey; whisky; wine; hotel; motel.

Many databases limit their screening process to the qualitative screening as the Eikon database which flags companies as Compliant if the business activity is considered permissible by Islamic law without taking into account financial ratios (Aziz et al. 2020).

\subsubsection{Quantitative criteria: Financial Ratios.}

The business activity screening process is followed by the quantitative screening, conducted to further filter companies by using three financial ratios indicators related to debt, interest bearing assets and liquidity (receivable). Following Ho et al. (2012), we consider that a firm is Compliant if:

$$
\text { Debt }=\frac{\text { Total Debt }}{\text { Market value }}<33 \%
$$

Cash + Interest bearing securities $=\frac{\text { Cash }+ \text { Short term Investment }+ \text { Other Investment }}{\text { Market value }}<33 \%$ 
There is a consensus among International Islamic indexes and Islamic index providers regarding the debt threshold of one third inspired by understandings from the Quran (Ashraf et al., 2020). There seems also to be a consensus regarding the $33 \%$ as the standard benchmark and the maximum threshold limit for Cash plus Interest bearing securities. Despite this consensus regarding the two first screening ratios, the thresholds values for the liquidity screen ratio (Receivables) vary considerably between $33 \%$ and $67 \%$ because of different Shariah jurisdictions operated by different users with various screening objectives. We follow in our paper the recommendation made by (Ho et al., 2012) regarding the liquidity ratio threshold. This recommendation is based on the analysis of the screening processes practiced by 15 worldwide leading Islamic finance users.

It is also worth noticing that we use the market value when accounting for equity as practiced by the DJMI, Standard and Poor's Shariah Index and most of the international Islamic Indexes except for the MSCI using the book value of equity.

Applying the screening process allows us to create a binary variable labeled Compliant and which equals one if the firm satisfies the listed quantitative and qualitative criteria and qualifies as a Compliant firm and equals zero otherwise.

\section{Empirical Methodology and Findings}

\subsection{Distribution of the sample}

Table 1 shows the number of firms per industry during the first and the second quarter of 2020. The Industry classification is based on the industry definition on Kenneth French website. Note that we allow the firm to change the compliance status giving the change in the qualitative screening ratios. This explains the difference in the number of Compliant firms each quarter.

We include 2274 companies in our sample in the first quarter of $2020.30 \%$ are Compliant firms and the remaining $70 \%$ are non-compliant. In the second quarter we include 2201 companies. $32 \%$ are compliant firms and the remaining $68 \%$ are non-compliant. For both quarters, compliant firms are concentrated on the Health care and business equipment industries, while the non-compliant firms are mostly in the finance industry.

We report the summary statistics in Table 2 for Compliant and Non-compliant firms during the first (Panel A) and second (Panel B) quarters of 2020. The numbers reported represent the mean across firms as well as the standard deviation and the $10^{\text {th }}$ to $90^{\text {th }}$ percentile. A detailed definition of the variables is found in Table A.1.

The comparison between Compliant and Non-Compliant firms from a descriptive perspective breaks down into three steps. We start by the descriptive statistics of returns and volatility. We deal then with the average ratios used in the quantitative screening process. We finally focus on control variables and compare their summary statistics between compliant and non-compliant firms. 
As we can see from Table 2-Panel A, the raw quarterly returns for both firms' categories are negative during the first quarter of 2020. Note that the negative returns are less pronounced for Compliant companies. The quarterly returns equal $-13 \%$ and $-31 \%$ for Compliant and NonCompliant firms respectively. Turning our attention to the quarterly abnormal returns, we clearly observe that Compliant firms outperform the non-Compliant ones. In fact, the quarterly abnormal return is positive and equals to $6 \%$ for Compliant firms and is negative and equals to $-12 \%$ for nonCompliant firms. Panel B of Table 2 shows that the average quarterly returns and abnormal returns improve for both firms' groups in the second quarter of 2020. Note that, again, the Compliant group is performing better than the non-Compliant group. In fact, the quarterly average return(abnormal returns equals to $33 \%$ (11\%) for the Compliant firms and equals to $28 \%$ (5\%) for the Compliant firms.

Despite the high returns detected for Compliant firms, we find that the risk, measured by the quarterly total and idiosyncratic volatility, is lower for Compliant firms. During the first quarter of 2020 (Panel A) the quarterly total (idiosyncratic) volatility equals to 63\% (37\%) for the Compliant firms compared to 68\% (39\%) for others. The second quarter of 2020 (Panel B) displays similar results. The quarterly total (idiosyncratic) volatility equals to $59 \%$ (37\%) for the Compliant firms compared to $73 \%$ (39\%) for others.

Table 2 also displays the average ratios used in our quantitative screening: the Debt, Receivable and Cash + Interest bearing securities ratios. As expected, the values of the ratios listed are lower for Compliant firms compared to the non-Compliant ones during both quarters.

We end our statistics' comparison by focusing on control variables. We observe first that Compliant firms present higher growth and Tobin's q ratios than Non-compliant firms in the first and second quarter of 2020. The Compliant (Non-compliant) growth ratio equals 3.36 (1.03) and 3.26 (1.05) during the first and second quarter respectively. The Compliant (Non-compliant) Tobin's q ratio equals 3.85 (1.71) and 3.76 (1.74) during the first and second quarter respectively. This demonstrates that Compliant firms exhibit valuable investment and growth opportunities. Combining the low leverage and high growth and Tobin's q characteristic of the Compliant group, weconfirm the findings of (Lang et al., 1996). The authors show that there is a negative relation between leverage and future growth and explain that leverage should have a negative effecton growth for firms doing poorly (in our case COVID-19 crisis) because of a lack of recognized investment opportunities and poor managerial performance.

By examining second, the size variable in Panels A and B, we find that the non-Compliant firms are slightly larger than Compliant firms. The cash flows from operating activities, CFO, arethen slightly higher for Compliant firms during the first and second quarter of 2020. Contrary to expectations, we see that the accounting performance measure, ROE, as well as the dividend are higher for Non-Compliant firms for both quarters. The cash is finally found to be higher for Compliant firms compared to others.

Although there are quite large difference between the $10^{\text {th }}$ and $90^{\text {th }}$ percentiles of the variablesin Table 2 for both firms categories, the standard deviation is fairly low suggesting low dispersionof the data points.

These results motivate us to look more carefully at the effect of the compliance on the crosssectional quarterly stocks abnormal returns and to examine the link between the performance of Compliant firms and the COVID-19 pandemic using differences-in-differences regressions for daily abnormal returns. 


\subsection{Quarterly Cross-sectional Regressions}

We investigate the effect of compliance status on the quarterly firm performance during the first and second quarter in 2020 by running the following quarterly regression:

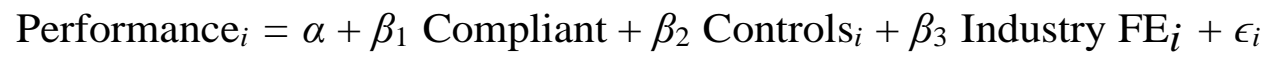

The dependent variable Performance ${ }_{i}$ is either the quarterly abnormal return of firm $i$, the quarterly idiosyncratic volatility of firm $i$ or the quarterly total volatility of firm $i$. Compliant as defined previously, is the binary variable equal to one if the firm is compliant and to zero otherwise. All Control variables are winsorized at the $1 \%$ and $99 \%$ levels. Tables 3, 4 and 5 present the regression results of equation 4 .

Giving that the first quarter of 2020 represents the outbreak of the COVID-19 virus, we hypothesize that the effect will be more pronounced during the first quarter compared to the secondone.

First, we estimate the cross-sectional regressions of quarterly abnormal returns. Table 3 displays the regression coefficients of the quarterly abnormal returns on companies' compliance status, represented by the variable Compliant during the two first quarters of 2020. In the first column of quarter 1 and quarter 2, we include the compliant status dummy as the main independent variable. In the second column we add cash, leverage, Tobin's q, dividend, CFO, ROE and growth as control variables. The control variables are described in detail is Table A.1. To make sure that ourcoefficients are not driven by special industry characteristics, we control for industry fixed effect (Industry FE) under all the specifications. Standard errors are robust for heteroscedasticity.

The effect of firms' compliance on abnormal returns is positive and significant at $0.1 \%$ level (respectively 5\% level) during the first quarter (respectively the second quarter) with and without including the control variables. As anticipated, the loading of the compliance status, $\beta_{1}$, is smallerand less significant during the second quarter of 2020. In particular, after adding the control variables, it is equal to 0.116 with a $t$ statistic of 6.27 in the first quarter and only 0.0 .034 with a $t$ statistic of 6.27 in the second quarter. This decline in the effect of the compliance status, $\beta_{1}$, might be explained by the major government actions to support the economy and the financial system.

Second, to further document the resiliency of compliant companies' stocks, we run the crosssectional regressions of equation 4 using as dependent variable the quarterly idiosyncratic volatility. The construction of the quarterly unsystematic risk is described in Table A.1. Table 4 shows that the effect of the compliance status on idiosyncratic volatility is significantly negative at $0.1 \%$

level before and after including the control variables. This is true for both the first and second quarters. During the first (second) quarter, the loading on the compliance status equals -0.0398 $(-0.0388)$ with a $t$ statistic of $-3.81(-3.56)$.

Thus, we conclude that compliant firms display lower firm-specific volatility of stock returns during the first two quarters of 2020. 
Third, we run the regressions described in equation 4 using the quarterly total volatility as independent variable. The total volatility is the standard deviation of stock returns. Table A.1 providesthe detailed construction of the total volatility. Table 5 presents the regressions' results, with and without including the control variables. Similarly to Table 4, we find that the loading on the Com-pliant variable, $\beta_{1}$, is negative and highly significant during quarters 1 and 2 of 2020 . Surprisingly, the negative effect is more pronounced during the second quarter. Including the control variables, the regression coefficients are shown in column 2 of both quarters: $\beta_{1}$ is respectively equal to -0.0524 $(t$ statistic $=-4.20)$ and $-0.0948(t$ statistic $=-6.71)$ during quarter 1 and quarter 2 respectively.

Our findings in Table 4 and Table 5 suggest that the out-performance of Compliant stock returns during the pandemic is not explained by a higher risk. However, it might be explained by the low leverage and the valuable investment and growth opportunities of compliant stocks as discussed inthe Table 2.

\subsection{Daily difference-in-differences regressions}

To better discern the effect of compliance on the firm financial performance, measured by the daily abnormal returns and daily volatility, during the COVID-19 crisis, we employ the difference-indifference methodology. Giving that our study focuses on the COVID-19 period, we need to identify precisely the beginning and the end of the crisis. To do so, we plot the daily $S \& P 500$ index value in Figure 1.

Figure 1 depicts first, that the stock market started to decline on February 24th, 2020 shown by the first vertical line. This date marks the start of the fever period (Ramelli \& Wagner, 2020 and Albuquerque et al., 2020) and the first lock-down in European soil, specifically, Northern Italy. Second, we observe that the stock market started to rebound on April 17th, 2020, shown by the second vertical line. The rebound of the financial market corresponds to the date of the announcementmade by Trump regarding the three-stage process for the United States to end up the pandemic shutdown. Therefore, February 24th and April, 17th correspond respectively, to the beginning and the end of the COVID-19 crisis.

The difference-in-difference model is giving by the following regression:

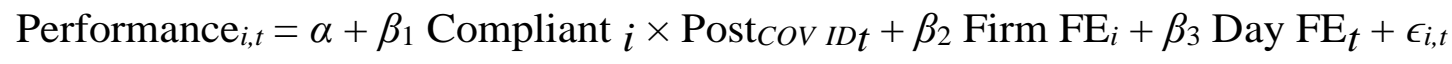

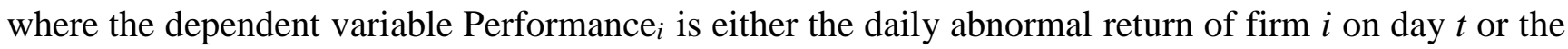
daily volatility of firm $i$ on day $t$. The period of study is from January 1st, 2020 to April 17th, 2020. Post $C O V$ IDt is a dummy variable and equals 1 for each day from February 24 until April 17, and zero otherwise. 
First, we focus on the effect of compliance on the daily returns during the COVID-19 crisis. Table 6 presents the results of the difference-in-difference regression where the dependent variable in equation 5 is the daily abnormal return. The first column displays the regressions' coefficients without firm (Firm FE) and day (Day FE) fixed effects (specification (1)). The second column presents the results taking on consideration both firm and day fixed effects (specification (2)). Standard errors are clustered by day and firm under both specifications. The coefficient of interest is $\beta_{1}$, which corresponds to the interaction term between the Post $C O V I D$, and the compliance status of the firm. This coefficient measures whether Compliant firm experienced a greater increase in abnormal returns from February 24th to April 17th.

Table 6 shows the positive effect from companies compliant during the treatment period (Covid-19 crisis). Under specification (1), we show that the estimated coefficient associated with the interaction between Post Covidt and Compliant is positive (0.273) and significant ( $t$ statistic $=6.27$ ). This positive and significant coefficient suggests that compliant companies perform better than noncompliant companies during the COVID-19 crisis period. In particular compliant firms earn an average abnormal daily return of $0.273 \%$ relative to conventional firms from February 24th, 2020 to April 17th, 2020. This corresponds to a cumulative abnormal return of $14.74 \%$ over the 54 days of crisis. While suggestive, this specification is not entirely appropriate since it does not control for any individual or day characteristics that might explain the rise in the daily abnormal returns for Compliant firms. Therefore, under specification (2) where we control for firm andday fixed effect, the estimated coefficient associated with the interaction between Post CoviDt and Compliant is again positive (0.26) and significant $(t$ statistic $=7.44)$.

Second, we concentrate on the effect of firms' compliance on the daily volatility during the COVID-19 crisis. Following (Albuquerque et al., 2020), we use the daily price-range as a proxyfor the daily volatility. Table 7 presents the results of the difference-in-difference regression where the dependent variable in equation 5 is the daily price-range. The first (second) column displays the regressions coefficients without (with) firm and day fixed effects. Standard errors are clusteredby day and firm under both specifications. The coefficient of interest is $\beta_{1}$ measures whetherCompliant firm experienced a greater increase in daily volatility from February 24th to April 17th.Column (1) in Table 7 shows that the estimated coefficient associated with the interaction be- tween PostcovID and Compliant is negative $(-0.0158)$ and significant $(t$ statistic $=-36.33)$. This model indicates that there was a highly significant decrease in the daily volatility during the COVID-19 period for compliant firms compared to others. In particular, compliant firms display an average daily volatility of $0.0158 \%$ lower than Non-compliant firms from February 24th, 2020 to April 17th, 2020. This corresponds to a 54 days cumulative daily volatility of $0.85 \%$. We controlfor fixed firm and fixed day effects in column (2) and obtain similar results. The estimated coefficient associated with the interaction between Post COVIDt and Compliant is negative (-0.0169)and significant with a $t$ statistic equal to -19.24 . This finding means that compliant stocks are less volatile than non-compliant 
companies during the COVID-19 period.

4. To conclude, we provide empirical evidence that the high performance of compliant firms is well revealed through the higher daily abnormal returns and lower daily volatility compared to non-compliant firms. Conclusion

The rapid spread of COVID-19 has tremendously affected stock markets all over the world. Usingcompliant mutual funds and stock market Islamic indexes, Islamic finance formed a sustainable form of finance that survived the consequences of previous financial crisis.

Our paper intends to address the question whether individual Compliant stocks would show similar resilience during the coronavirus pandemic than their conventional counterparts. and pro-vides an original empirical analysis as it stands out from the extant literature in many aspects.

First, while previous research focuses on Compliant mutual funds and Islamic stock market indexes, we filter our sample of North American companies into Compliant and Non-compliant groups. Compliant firm must satisfy the qualitative and quantitative screening process defined by Islamic law, Second, our paper analyzes the quarterly stock performance using individual crosssectional regressions during the first two quarters of 2020. To better discern the effect of compliance on the firm financial performance, measured by the daily abnormal returns and daily volatility, during the COVID-19 crisis, we employ the difference-in-difference methodology. February 24thand April, 17th correspond respectively, to the beginning and the end of the COVID-19 crisis.

We find that compliant stocks outperform their conventional counterparts during the pandemic and that this outperformance is not associated with higher risk as compliant stocks are evidenced to be less volatile than their non-Compliant peers during the covid-19 period.

While our article fills a gap in the existing literature related to the impact of COVID-19 pandemic on Islamic stocks performance, it also suggests new avenues for research. In the next step, we will examine the compliance impact of the global financial market. To do so, we will expand the data sample to include Middle Eastern, Asian and European Countries. 
Table 1: Industrial distribution of Compliant and Non-Compliant companies during the first and the second quarter of 2020

\begin{tabular}{|c|c|c|c|c|}
\hline Industry sector & $\mathrm{CC}$ & $\mathrm{NCC}$ & Total & Weight $(\%)$ \\
\hline \multicolumn{5}{|l|}{ Ouarter 12020} \\
\hline consumer Nondurables & 30 & 10 & 106 & 4.66 \\
\hline Consumer Durables & 14 & $3 y$ & 53 & 2.33 \\
\hline Manutacturıng & 13 & 140 & 213 & 9.31 \\
\hline \multicolumn{5}{|l|}{ U1l, Gas, and Coal Extraction and } \\
\hline $\begin{array}{l}\text { Products } \\
\text { Chemicals and Allied Products }\end{array}$ & 22 & 43 & 05 & 2.80 \\
\hline Business Equipment & 249 & $1 \%$ & 419 & 18.43 \\
\hline \multicolumn{5}{|l|}{$\begin{array}{l}\text { Telephone and Ielevision } \\
\text { Transmission }\end{array}$} \\
\hline $\begin{array}{l}\text { Transmission } \\
\text { Utilities }\end{array}$ & 5 & 81 & 80 & 3.18 \\
\hline \multicolumn{5}{|l|}{$\begin{array}{l}\text { Wholesale, Ketall, and some } \\
\text { Services }\end{array}$} \\
\hline \multirow{2}{*}{\multicolumn{5}{|c|}{$\begin{array}{l}\text { Healthcare, Medical Equipment, } \\
\text { and Drugs }\end{array}$}} \\
\hline & 0 & 414 & 414 & 18.21 \\
\hline Uther & 15 & 221 & 296 & $13.0^{\prime}$ \\
\hline T'otal & 672 & 1602 & 2274 & 100.00 \\
\hline \multicolumn{5}{|l|}{ Quarter 22020} \\
\hline Consumer Nondurables & 21 & 10 & IU3 & 4.68 \\
\hline Consumer Durables & 19 & 30 & 44 & 2.23 \\
\hline Manutacturıng & 15 & 133 & 208 & y.45 \\
\hline \multicolumn{5}{|l|}{$\begin{array}{l}\text { U1, Gas, and Coal Extraction and } \\
\text { Products }\end{array}$} \\
\hline $\begin{array}{l}\text { Products } \\
\text { C'nemicals and Allied Products }\end{array}$ & 26 & 40 & 60 & 3.00 \\
\hline Business Equipment & 254 & 160 & 414 & 18.81 \\
\hline 'lelephone and I'elevision & 10 & 54 & 64 & $\begin{array}{l}\text { Telephone and l'elevision } \\
\text { Transmission }\end{array}$ \\
\hline $\begin{array}{l}\text { Transmission } \\
\text { Utillties }\end{array}$ & 4 & 11 & 81 & 3.68 \\
\hline \multicolumn{5}{|l|}{$\begin{array}{l}\text { Wholesale, Ketall, and some } \\
\text { Services }\end{array}$} \\
\hline \multirow{2}{*}{$\begin{array}{l}\text { Services } \\
\text { Healthcare, Medical Equipment, } \\
\text { and Drugs } \\
\text { Hinance }\end{array}$} & 160 & 121 & 281 & 13.04 \\
\hline & u & 384 & 384 & $1 \% .45$ \\
\hline Uther & 84 & 204 & 288 & 13.08 \\
\hline 'lotal & 713 & 1488 & 2201 & 100.00 \\
\hline
\end{tabular}

The table details the Industrial distribution of Compliant and Non-compliant companies during the first (Panel A) and second (Panel B) quarter of 2020. A firm is considered Compliant if it satisfy the quantitative and qualitative screening criteria defined by the Islamic law. Industry classification is based on Fama French 12 industries. We obtain the industry classification from Kenneth French website. 
Table 2: Summary statistics: Compliant and Non-Compliant companies during the first and the second quarter of 2020

\begin{tabular}{|c|c|c|c|c|c|c|c|}
\hline \multicolumn{8}{|l|}{$\begin{array}{l}\text { Panel A : Quarter 1, } \\
2020\end{array}$} \\
\hline Compliant firms & mean & $\mathrm{sd}$ & p10 & $\mathrm{p} 25$ & p50 & p75 & p90 \\
\hline Quarterly return & -0.13 & 032 & -0.38 & 0.2 & -0.13 & -0.02 & 0.10 \\
\hline Quarterly abnormal return & U.U6 & $u_{2}$ & $-0.2 U$ & $\begin{array}{c}6 \\
0.0\end{array}$ & U.UJ & U.1/ & $0.2 y$ \\
\hline Quarterly total volatılity & 0.03 & $u_{0}^{2}$ & U.4J & U. & U.ou & U./2 & U. \\
\hline Uyarterly 1diosyncratic & 0.31 & 0,1 & 0.22 & 0.20 & 0.34 & 0.43 & 0.56 \\
\hline Debt & 0.12 & $u_{0}^{\prime}$ & U.U1 & U.U3 & U.1U & 0.20 & 0.21 \\
\hline Keceivables & 0.15 & $u_{0}^{0}$ & U.U4 & u.ur & 0.14 & U.LL & $0.2 y$ \\
\hline Lasn + Interest bearıng & u.uY & $u_{8}$ & U.UI & u.u3 & $0.0 /$ & U.14 & 0.21 \\
\hline $\begin{array}{l}\text { Securties } \\
\text { Growth }\end{array}$ & 3.50 & 2 & $1.2 y$ & 1.14 & 2.01 & 4.20 & 0.98 \\
\hline Iobın's q & 3.80 & 2,3 & 1.13 & 2.18 & 3.00 & $4 . / 1$ & 1.42 \\
\hline Size & 1.53 & 10 & 5.53 & 0.38 & 1.36 & ૪.ग1 & $y .18$ \\
\hline $\mathrm{CHU}$ & u.ur & $u_{4}^{3}$ & -0.00 & U.UD & U.11 & 0.10 & 0.21 \\
\hline Dividend & U./I & 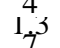 & u.vo & u.uv & u.Uu & 1.21 & 2.23 \\
\hline KUE & U.UI & u's & $-0.3 y$ & $\overline{0_{3}} 0$ & U.11 & 0.20 & 0.30 \\
\hline Cash & 0.26 & $U_{3}^{2}$ & 0.02 & $0.0 \%$ & 0.18 & 0.39 & 0.63 \\
\hline Observations & $6 / 2$ & & & & & & \\
\hline \multicolumn{8}{|l|}{ Non-Compliant firms } \\
\hline Quarterly return & -0.31 & 0.2 & -0.62 & $\overline{0.4}$ & -0.30 & -0.14 & -0.01 \\
\hline Quarterly abnormal return & -0.12 & $\mathrm{U}_{3} 2$ & -0.40 & $0 \div 2$ & -0.11 & U.U1 & U.15 \\
\hline Quarterly total volatılity & 0.68 & $v_{6}$ & 0.41 & 0.53 & 0.64 & 0.19 & 0.98 \\
\hline Uuarteriy 1diosyncratic & $0.3 y$ & $u_{1}^{2}$ & 0.21 & 0.20 & U.3J & $0.4 /$ & 0.04 \\
\hline $\begin{array}{l}\text { volat1lity } \\
\text { Debt }\end{array}$ & 1.00 & $3 y$ & U.IU & 0.50 & $0 . / 1$ & 1.22 & 3.30 \\
\hline Keceivables & $1 . y 9$ & 4.3 & u.ur & 0.19 & 0.43 & 1.18 & 0.90 \\
\hline Lasn + Interest bearıng & 0.35 & $u_{5}^{4} \mathrm{x}$ & U.UL & u.uo & U.10 & U.58 & U./2 \\
\hline Growth & 1.03 & $1_{5}^{2}$ & U.15 & U.32 & 0.00 & 1.22 & 2.11 \\
\hline Iobın’s q & $1 . / 1$ & $1_{2}^{3}$ & u.yy & 1.00 & 1.52 & 1.80 & 2.84 \\
\hline Size & 8.62 & 1,1 & 0.48 & 1.40 & 8.52 & 9.60 & 10.85 \\
\hline $\mathrm{CHU}$ & U.US & u. & -0.01 & U.U2 & u.vo & U.10 & 0.15 \\
\hline Dividend & 2.11 & 2.1 & u.uo & u.uv & 1.54 & $2.9 y$ & 3.21 \\
\hline KUE & U.U4 & 0.4 & -0.21 & U.UL & u.vy & U.15 & U.2I \\
\hline Cash & 0.13 & $u_{9}^{\prime}=1$ & 0.01 & 0.02 & U.US & 0.14 & 0.35 \\
\hline
\end{tabular}




\begin{tabular}{|c|c|c|c|c|c|c|c|}
\hline Ubservations & 1602 & & & & & & \\
\hline \multicolumn{8}{|l|}{$\begin{array}{l}\text { Panel B : Quarter 2, } \\
2020\end{array}$} \\
\hline Compliant firms & mean & sd & $\mathrm{p} 10$ & $\mathrm{p} 25$ & p50 & p75 & p90 \\
\hline Quarterly return & 0.33 & 0.2 & 0.07 & 0.16 & 0.28 & 0.44 & 0.66 \\
\hline Quarterly abnormal return & U.11 & $u_{5}^{0}$ & -0.13 & $\overline{0} 0$ & U.Uo & $u .2 U$ & 0.42 \\
\hline Quarterly total volatılity & U.Jy & $\mathrm{U}_{2} 2$ & 0.50 & 0.44 & U.ग0 & U.6y & U.83 \\
\hline \multirow{2}{*}{$\begin{array}{l}\text { Uyarterly 1diosyncratic } \\
\text { volatility } \\
\text { Debt }\end{array}$} & 0.51 & $u_{0}^{2} 1$ & 0.19 & 0.25 & 0.33 & 0.44 & U.J/ \\
\hline & 0.12 & $u_{0} 1$ & U.UI & U.U3 & U.UY & $U .2 U$ & 0.28 \\
\hline Keceivables & U.15 & $u_{0}^{u}$ & U.U4 & U.U/ & U.11 & U.1Y & 0.20 \\
\hline \multirow{2}{*}{$\begin{array}{l}\text { Uash + Interest bearıng } \\
\text { Securities } \\
\text { Growth }\end{array}$} & U.Uช & U.u & U.UI & U.U3 & U.Uo & 0.12 & U.18 \\
\hline & 3.20 & 2.2 & 1.21 & $1.6 /$ & 2.48 & 4.08 & 0.69 \\
\hline I obin's q & 3.10 & 20 & $1 . / 1$ & 2.14 & 3.00 & 4.50 & 1.13 \\
\hline Size & 1.53 & $1_{4}^{6}$ & 5.53 & 0.32 & 1.33 & ૪.54 & Y.81 \\
\hline (mean) cto & $U . U /$ & $u_{4}^{4}$ & -0.11 & U.U4 & U.1U & U.1) & 0.21 \\
\hline Dividend & U. 14 & $18^{4}$ & U.UU & U.UU & U.UU & 1.21 & 2.22 \\
\hline KUE & -0.01 & $u_{3}^{8}$ & -0.40 & $\overline{0.0}$ & 0.10 & $U .2 U$ & U.50 \\
\hline C'ash & 0.26 & $u_{4}^{2}$ & 0.02 & $0.0 \%$ & 0.19 & 0.41 & 0.65 \\
\hline Ubservations & 713 & & & & & & \\
\hline \multicolumn{8}{|l|}{ Non-Compliant firms } \\
\hline Quarterly return & 0.28 & 0.2 & 0.02 & 0.12 & 0.24 & 0.41 & 0.60 \\
\hline Quarterly abnormal return & U.US & 0.2 & $-U .2 U$ & $0 \overline{0} 1$ & U.UI & U.10 & U.34 \\
\hline Quarterly total volatılıty & U./3 & $u_{\dot{4}}^{3}$ & U.4U & U.J3 & U.oy & U.ð/ & 1.06 \\
\hline \multirow{2}{*}{$\begin{array}{l}\text { Uuarteriy 1diosyncratic } \\
\text { volatility } \\
\text { Debt }\end{array}$} & U.3y & $u_{4}^{2}$ & $U .21$ & 0.20 & U.34 & $0.4 /$ & 0.03 \\
\hline & 1.22 & 2,4 & U.UY & 0.35 & U.64 & 1.38 & 2.52 \\
\hline KeceivabIes & 1.19 & $3, y$ & U.Ur & U.1/ & U.3y & U.90 & 0.48 \\
\hline \multirow{2}{*}{$\begin{array}{l}\text { Lash + Interest bearing } \\
\text { securities } \\
\text { Growth }\end{array}$} & 0.34 & $u_{3}^{2} x$ & U.U3 & U.Uo & 0.10 & 0.55 & $0.0 /$ \\
\hline & $1 . U 2$ & $12^{3}$ & 0.10 & 0.52 & U.0/ & 1.21 & 2.21 \\
\hline I obin's q & 1.14 & $18^{2}$ & U.YY & 1.06 & 1.35 & 1.80 & L.ð/ \\
\hline Size & $8.0 y$ & 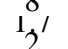 & 0.50 & 1.35 & ૪.ग / & y. /1 & $11 . \mathrm{UU}$ \\
\hline (mean) cto & U.U6 & 0 & -0.01 & U.U2 & U.U6 & 0.10 & U.15 \\
\hline Dividend & 2.01 & 20 & U.UU & U.UU & 1.40 & 3.04 & 3.15 \\
\hline KUE & U.US & $u_{6}^{2}$ & $-U .2 U$ & U.U3 & U.UY & U.1) & 0.21 \\
\hline C'ash & 0.12 & $u_{8}^{0}$ & U.UI & $U . U 2$ & U.US & U.14 & 0.33 \\
\hline Ubservations & 1488 & & & & & & \\
\hline
\end{tabular}

This table reports the summary statistics of all variables included in the study for Compliant and Un-compliant firms. A firm is considered Compliant if it satisfy the quantitative and qualitative screening criteria defined by the Islamic law. The numbers reported represent the mean across firms as well as the standard deviation and the $10^{\text {th }}$ to $90^{\text {th }}$ percentile on the first (Panel A) and the second (Panel B) quarter of 2020. A detailed definition of the variables is found in Table A.1. 
3rd International Conference on Advanced Research in

MANAGEMENT, BUSINESS \& FINANCE
MUNICH, GERMANY

29-31 July, 2021

Table 3: Cross-sectional regressions for quarterly abnormal returns

\begin{tabular}{|c|c|c|c|c|c|c|}
\hline & $\begin{array}{c}\text { Abnormal } \\
\text { return }_{\boldsymbol{i}}\end{array}$ & $\begin{array}{l}\text { Quarter } \\
1\end{array}$ & $\begin{array}{c}\text { Abnormal } \\
\text { return }_{\boldsymbol{i}}\end{array}$ & $\begin{array}{c}\text { Abnormal } \\
\text { return }_{\boldsymbol{i}}\end{array}$ & $\begin{array}{l}\text { Quarter } \\
2\end{array}$ & $\begin{array}{c}\text { Abnormal } \\
\operatorname{return}_{\boldsymbol{i}}\end{array}$ \\
\hline Compliant & $\begin{array}{c}0.134^{* * *} \\
(12.11)\end{array}$ & & $\begin{array}{c}0.116^{* * *} \\
(9.01)\end{array}$ & $\begin{array}{c}0.0325^{*} \\
(2.56)\end{array}$ & & $\begin{array}{c}0.0340^{*} \\
(2.37)\end{array}$ \\
\hline Cash & & & $\begin{array}{c}0.122^{* * *} \\
(3.71)\end{array}$ & & & $\begin{array}{c}0.0947^{*} \\
(2.19)\end{array}$ \\
\hline Leverage & & & $\begin{array}{c}0.0684^{*} \\
(2.41)\end{array}$ & & & $\begin{array}{c}0.209^{* * *} \\
(5.89)\end{array}$ \\
\hline Tobin's q & & & $\begin{array}{l}- \\
0.0579 \\
*(- \\
2.22)\end{array}$ & & & $\begin{array}{l}- \\
0.0910 \\
*(- \\
2.11)\end{array}$ \\
\hline Dividend & & & $\begin{array}{c}-0.00692^{* *} \\
(-3.25)\end{array}$ & & & $\begin{array}{c}0.00266 \\
(0.99)\end{array}$ \\
\hline cfo & & & $\begin{array}{c}-0.142^{*} \\
(-2.25)\end{array}$ & & & $\begin{array}{l}- \\
0.372^{* *} \\
{ }^{*}(- \\
4.54)\end{array}$ \\
\hline ROE & & & $\begin{array}{c}0.00320 \\
(0.24)\end{array}$ & & & $\begin{array}{c}-0.0372^{*} \\
(-2.49)\end{array}$ \\
\hline Growth & & & $\begin{array}{c}0.0671^{*} \\
(2.54)\end{array}$ & & & $\begin{array}{l}0.103^{*} \\
(2.33)\end{array}$ \\
\hline Constant & $\begin{array}{c}-0.107^{* * *} \\
(-18.18)\end{array}$ & & $\begin{array}{c}-0.101^{* * *} \\
(-5.54)\end{array}$ & $\begin{array}{c}0.0604^{* * *} \\
(8.90)\end{array}$ & & $\begin{array}{c}0.0388 \\
(1.21)\end{array}$ \\
\hline $\mathrm{N}$ & 2274 & & 2274 & 2201 & & 2201 \\
\hline
\end{tabular}




\section{MANAGEMENT, BUSINESS \& FINANCE}

$\begin{array}{lcccc}\text { R squared } & 0.209 & 0.235 & 0.0663 & 0.130 \\ \text { Industry } & \text { yes } & \text { yes } & \text { yes } & \text { yes } \\ \text { fixed } & \text { yes } & \text { yes } & \text { yes } & \text { yes } \\ \text { effects } & & & & \\ \text { Robust } & & & \\ \text { standard } & & & & \\ \text { errors } & & & \end{array}$

This table reports the results of the following regression:

$$
\begin{gathered}
\text { Performance }_{\boldsymbol{i}}=\alpha+\beta_{1} \text { Compliant }+\beta_{2} \text { Controls }_{\boldsymbol{i}}+\beta_{3} \text { Industry }_{\mathrm{FE}_{\boldsymbol{i}}} \\
+\epsilon_{\boldsymbol{i}},
\end{gathered}
$$

where the dependent variable Performance ${ }_{i}$ is the quarterly abnormal return of firm $i$. Compliant, the variable of interest, is a binary variable equals one if the firm is compliant and zero otherwise. We construct the Compliant using the qualitative and quantitative screening process detailed in the subsection 3.1. We run the regression on the first and second quarters of 2020, separately under two specifications: without firm controls (specification 1), with firm controls (specification 2). For both specifications, we control for the industry fixed effects. Control variables are winsorized at the $1 \%$ and $99 \%$ levels. A detailed definition of the dependent and independent variables is found in Table A.1. $t$

statistics are in parenthesis and are adjusted for heteroskedasticity. ${ }^{*} p<0.05,{ }^{* *} p<0.01,{ }^{* * *} p<$ 0.001 .

\begin{tabular}{|c|c|c|c|c|c|}
\hline & $\begin{array}{c}\text { Idio } \\
\text { volatility } i\end{array}$ & $\begin{array}{l}\text { Quarter } \\
1\end{array}$ Idio volatility $i$ & $\begin{array}{c}\text { Idio } \\
\text { volatility } i\end{array}$ & $\begin{array}{l}\text { Quarter } \\
2\end{array}$ & $\begin{array}{c}\text { Idio } \\
\text { volatility } i\end{array}$ \\
\hline \multirow[t]{4}{*}{ Compliant } & - & - & - & & - \\
\hline & $0.0703^{*}$ & $0.0398^{*}$ & $0.0590 *$ & & $0.0388^{*}$ \\
\hline & $* *(-$ & $* *(-$ & $* *(-$ & & $* *(-$ \\
\hline & 6.91) & $3.81)$ & 6.09) & & $3.56)$ \\
\hline Cash & & $\begin{array}{c}0.174^{* * *} \\
(6.79)\end{array}$ & & & $\begin{array}{c}0.130^{* *} \\
(2.81)\end{array}$ \\
\hline Leverage & & $\begin{array}{c}0.124^{* * *} \\
(4.59)\end{array}$ & & & $\begin{array}{c}0.169^{* * *} \\
(5.60)\end{array}$ \\
\hline Tobin's q & & $\begin{array}{c}-0.00779 \\
(-0.37)\end{array}$ & & & $\begin{array}{c}-0.0964 \\
(-1.78)\end{array}$ \\
\hline Dividend & & $\begin{array}{c}-0.00642^{* * *} \\
(-3.61)\end{array}$ & & & $\begin{array}{c}-0.00254 \\
(-0.96)\end{array}$ \\
\hline
\end{tabular}

Table 4: Cross-sectional regressions for quarterly idiosyncratic volatility 


\title{
MANAGEMENT, BUSINESS \& FINANCE
}

29-31 July, 2021

cfo

\author{
$0.344^{* *}$ \\ *(-

$0.467^{* *}$

$*(-$

ROE

0.0416

*(-

2.23)

$0.0367^{*}$

** $(-$

Growth

0.00253

$3.74)$

$(0.12)$

\begin{tabular}{lcccc} 
Constant & $\begin{array}{c}0.406^{* * *} \\
(71.99)\end{array}$ & $\begin{array}{c}0.379^{* * *} \\
(27.57)\end{array}$ & $\begin{array}{c}0.402^{* * *} \\
(69.04)\end{array}$ & $\begin{array}{c}0.424^{* * *} \\
(10.21)\end{array}$ \\
\hline $\mathrm{N}$ & 2274 & 2274 & 2201 & 2201 \\
$\mathrm{R}$ squared & 0.111 & 0.212 & 0.0709 & 0.169 \\
Industry & yes & yes & yes & yes \\
fixed & yes & yes & yes & yes \\
effects & & & & \\
$\begin{array}{l}\text { Robust } \\
\text { standard }\end{array}$ & & & & \\
errors & & & & \\
\hline
\end{tabular}

This table reports the results of the following regression:

$$
\begin{gathered}
\text { Performance }_{\boldsymbol{i}}=\alpha+\beta_{1} \text { Compliant }_{+}+\beta_{2} \text { Controls }_{\boldsymbol{i}}+\beta_{3} \text { Industry FE }_{\boldsymbol{i}} \\
+\epsilon_{\boldsymbol{i}},
\end{gathered}
$$

where The dependent variable Performance $i_{i}$ is the quarterly idiosyncratic volatility of firm $i$. Compliant, the variable of interest, is a binary variable equals one if the firm is compliant and zero otherwise. We construct the Compliant using the qualitative and quantitative screening process detailed in the subsection 3.1. We run the regression on the first and second quarters of 2020, separately under two specifications: without firm controls (specification 1), with firm controls (specification 2). For both specifications, we control for the industry fixed effects. Control variables are winsorized at the $1 \%$ and $99 \%$ levels. A detailed definition of the dependent and independent variables is found

in Table A.1. $t$ statistics are in parenthesis and are adjusted for heteroskedasticity. ${ }^{*} p<0.05,{ }^{* *} p$ $<0.01,{ }^{* * *}$

$p<0.001$. 
3rd International Conference on Advanced Research in

MANAGEMENT, BUSINESS \& FINANCE
MUNICH, GERMANY

29-31 July, 2021

Table 5: Cross-sectional regressions for quarterly total volatility

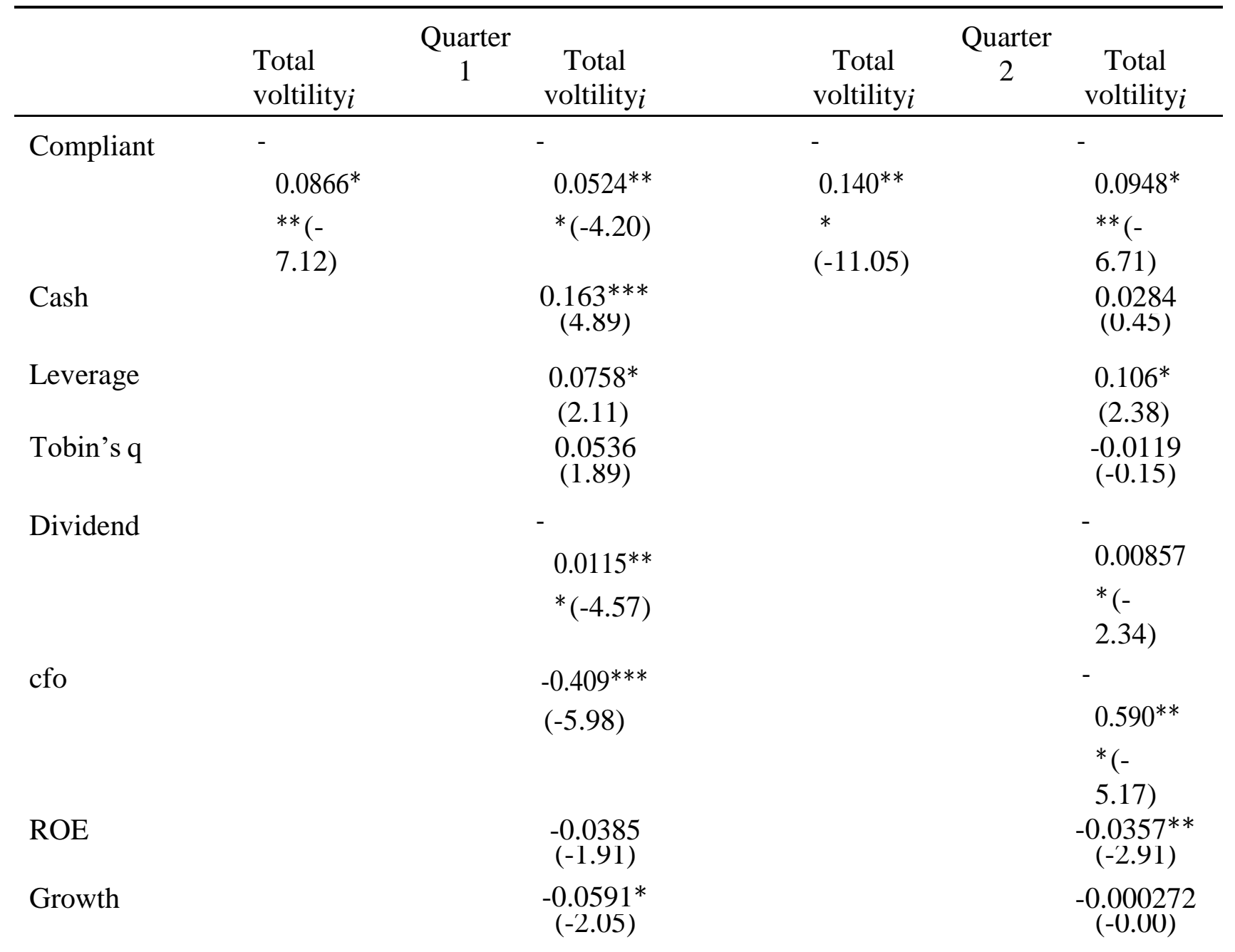




\section{MANAGEMENT, BUSINESS \& FINANCE}

\begin{tabular}{lcccc} 
Constant & $\begin{array}{c}0.690^{* * *} \\
(99.19)\end{array}$ & $\begin{array}{c}0.653^{* * *} \\
(37.35)\end{array}$ & $\begin{array}{c}0.726^{* * *} \\
(88.11)\end{array}$ & $\begin{array}{c}0.756^{* * *} \\
(12.77)\end{array}$ \\
\hline $\mathrm{N}$ & & & & \\
$\mathrm{R}$ squared & 2274 & 2274 & 2201 & 2201 \\
Industry & 0.0675 & 0.151 & 0.0875 & yes \\
fixed & yes & yes & yes & yes \\
effects & yes & & & yes \\
Robust & & & & \\
standard & & & & \\
errors & & & & \\
\hline
\end{tabular}

This table reports the results of the following regression:

$$
\begin{gathered}
\text { Performance }_{\boldsymbol{i}}=\alpha+\beta_{1} \text { Compliant }+\beta_{2} \text { Controls }_{\boldsymbol{i}}+\beta_{3} \text { Industry }_{\mathrm{FE}_{\boldsymbol{i}}} \\
+\epsilon_{\boldsymbol{i}},
\end{gathered}
$$

where the dependent variable Performance $i$ is the quarterly total volatility of firm $i$. Compliant, the variable of interest, is a binary variable equals one if the firm is compliant and zero otherwise. We construct the Compliant using the qualitative and quantitative screening process detailed in the subsection 3.1. We run the regression on the first and second quarters of 2020, separately under two specifications: without firm controls (specification 1), with firm controls (specification 2). For both specifications, we control for the industry fixed effects. Control variables are winsorized at the $1 \%$ and $99 \%$ levels. A detailed definition of the dependent and independent variables is found in Table A.1. $t$

statistics are in parenthesis and are adjusted for heteroskedasticity. ${ }^{*} p<0.05,{ }^{* *} p<0.01,{ }^{* * *} p<$ 0.001 .

Table 6: Difference-in-differences regression for daily abnormal returns. The sample period startsfrom January 1st 2020 to April 17th.2020

\begin{tabular}{lcc}
\hline & $\begin{array}{c}(1) \\
\text { Abnormal } \\
\text { return }_{i, t}\end{array}$ & $\begin{array}{c}(2) \\
\text { Abnormal } \\
\text { return }_{i, t}\end{array}$ \\
\hline Compliant & $0.215^{* * *}$ & $0.244^{*}$ \\
Post covid & $(11.07)$ & $(2.45)$ \\
& - & - \\
Compliant $\times$ Post $_{\text {covid }}$ & $0.213^{* * *}$ & $0.227^{* *}$ \\
& $(-7.85)$ & $*$ \\
& & $(-12.26)$ \\
& $0.273^{* * *}$ & $0.260^{* * *}$
\end{tabular}


Constant

\begin{tabular}{lcc} 
& $0.139^{* * *}$ & $0.139^{* *}$ \\
& $(-13.43)$ & $*$ \\
\hline $\mathrm{N}$ & & $(-4.36)$ \\
$\mathrm{R}$ squared & $1 / 90 / 1$ & $1 / 96 / 1$ \\
Firm fixed & 0.00161 & 0.000454 \\
effects Day & no & yes \\
fixed effect & no & yes \\
Robust standard errors & yes & yes \\
\hline
\end{tabular}

This table reports the results of a difference-in-differences estimation of daily abnormal returns during the period from January 1st, 2020 to April, 17th 2020. The difference-indifference model is giving by the following regression:

$$
\begin{gathered}
\text { Performance }_{i, t}=\alpha+\beta_{1} \text { Compliant }_{i} \times \text { Post }_{C O V I D t}+\beta_{2} \text { Firm FE }_{i} \\
+\beta_{3} \text { Day FE }_{t}+\epsilon_{i, t}
\end{gathered}
$$

where the dependent variable Performance ${ }_{i}$ is the daily abnormal return of firm $i$ on day $t$.

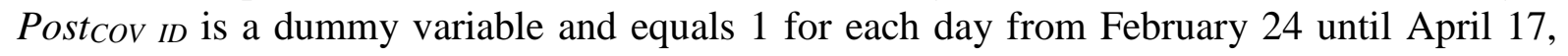
and zero otherwise. Compliant, the variable of interest, is a binary variable equals one if the firm is compliant and zero otherwise. We construct the Compliant using the qualitative and quantitative screening process detailed in the subsection 3.1. A detailed definition of the dependent and independent variables is found in Table A.1. We run the regression under two specifications: without firm and day fixed effect (specification 1), without firm and day fixed effect (specification 2). A detailed definition of the dependent and independent variables is found in Table A.1. Standard errors are clustered by firm and day. $t$ statistics are in parenthesis. ${ }^{*} p<0.05,{ }^{* *} p<0.01,{ }^{* * *} p<0.001$.

Table 7: Difference-in-differences regressions for the daily price range. The sample period startsfrom January 1st 2020 to April 17th.2020

Compliant $\times$ Post $_{\text {covid }}$ 


\begin{tabular}{lcc} 
& & $*(-$ \\
& & $19.24)$ \\
Constant & $0.0276^{* * *}$ & $0.0282^{* * *}$ \\
& $(278.76)$ & $(39.50)$ \\
\hline $\mathrm{N}$ R squared & $1796 / 1$ & $1796 / 7$ \\
Firm fixed & 0.273 & 0.318 \\
effects Day & no & yes \\
fixed effect & no & yes \\
Robust standard errors & yes & yes \\
\hline
\end{tabular}

This table reports the results of a difference-in-differences estimation of the daily price range during the period from January 1st, 2020 to April, 17th 2020. The difference-in-difference model is giving by the following regression:

$$
\begin{gathered}
\text { Performance }_{i, t}=\alpha+\beta_{1} \text { Compliant } i \times \text { Post }_{C O V I D t}+\beta_{2} \text { Firm FE }_{i} \\
+\beta_{3} \text { Day FE }_{t}+\epsilon_{i, t}
\end{gathered}
$$

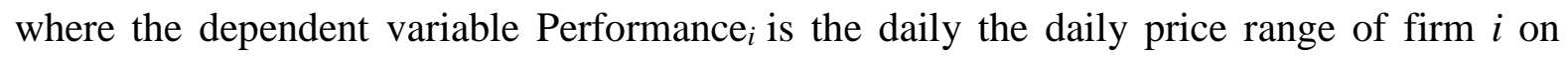
day $t$. Post COVID is a dummy variable and equals 1 for each day from February 24 until April 17, and zero otherwise. Compliant, the variable of interest, is a binary variable equals one if the firm is compliant and zero otherwise. We construct the Compliant using the qualitative and quantitative screening process detailed in the subsection 3.1. A detailed definition of the dependent and independent variables is found in Table A.1. We run the regression under two specifications: without firm and day fixed effect (specification 1), without firm and day fixed effect (specification 2). Standard errors

are clustered by firm and day. $t$ statistics are in parenthesis. ${ }^{*} p<0.05,{ }^{* *} p<0.01,{ }^{* * *} p<0.001$. 


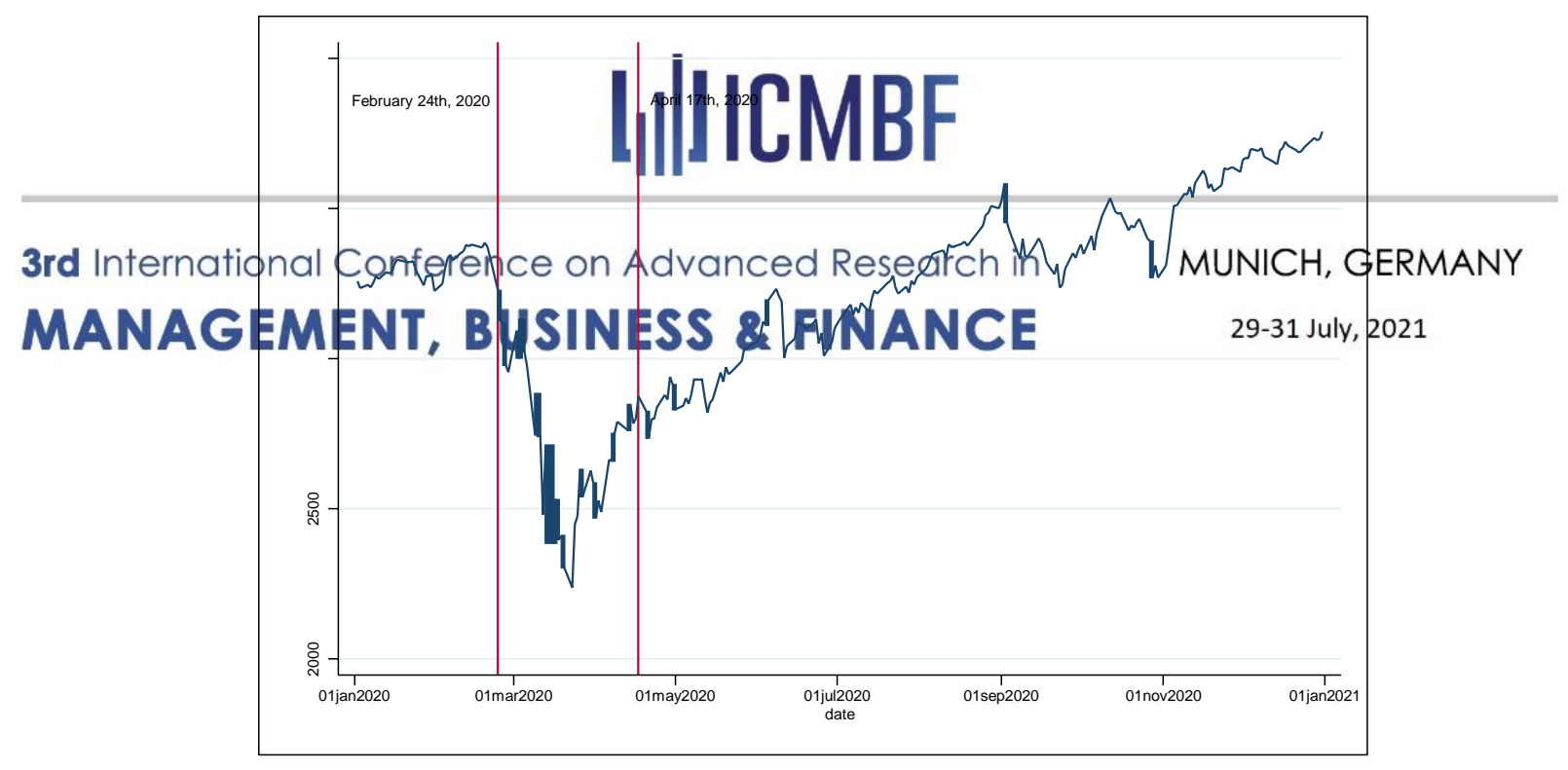

Figure 1: Daily S\&P 500 index value.

Figure 1 plots the daily observations from February 24th, 2020 to April $17^{\text {th }}, 2020$ represent the COVID period in our analysis. This is the area represented by thetwo vertical lines.

\section{An Appendix}

Table A.1: Variables' definitions

\begin{tabular}{ll}
\hline Variable & Definition \\
\hline Compliant & $\begin{array}{l}\text { Binary variable equals one if the firm is compliant and zero } \\
\text { otherwise. We construct the Compliant using the screening process } \\
\text { detailed in the subsection } 3.1 .\end{array}$ \\
& The quarterly raw returns for firm $i$ is the sum of daily logarithm \\
$\begin{array}{l}\text { Quarterly return } \\
\text { returns during }\end{array}$ & the quarter for firm $i$. We obtain the daily returns from CRSP. \\
$\begin{array}{l}\text { Daily Abnormal return } \\
\text { return of }\end{array}$ & The daily Abnormal return is the difference between daily logarithm \\
& $\begin{array}{l}\text { a stock and the CAPM beta times the daily logarithm return of the } \\
\text { market. The CAPM beta is estimated by using daily returns from } \\
\text { 2017 to 2020, where the market index is obtained from Kenneth } \\
\text { French website. }\end{array}$
\end{tabular}


3rd International Conference on Advanced Research in MANAGEMENT, BUSINESS \& FINANCE
MUNICH, GERMANY

29-31 July, 2021
Quarterly Abnormal returns of the first

Quarterly total volatility
The quarterly Abnormal return is measured over the whole period and the second quarter of 2020.

We first calculate the monthly total volatility by calculating the standard deviation of daily returns for the month. It is then annualized by multiplying by 252 . The quarterly total volatility is the average annualized monthly volatility for a giving quarter.

We first find the monthly idiosyncratic volatility by the

Quarterly idiosyncratic volatility linear regression of

daily stock returns on the Fama French factors and the Momentum factor. Theidiosyncratic volatility of stock $i$ for a given month is the square root of the

qums of fafulared residuals of this regression for all days in the month. is annualized by multiplying by 252 . The quarterly idiosyncratic volatility is

the average annualized monthly volatility for a giving quarter.

Growth

Market value (CSHO* PRCC) over Book value (AT). Annual data from Compustat (2019).

Table A.1:-Continued

\begin{tabular}{ll}
\hline Variable & Definition \\
\hline Tobin's q & $\begin{array}{l}\text { Book value of assets (AT) minus the book value of equity } \\
\text { (CEQ) plus themarket value of equity (CSHO*PRCC), all divided } \\
\text { by book value of assets (AT). Annual data from Compustat (2019). }\end{array}$ \\
Size & $\begin{array}{l}\text { Natural log of the book value of total asset (AT). Annual data from } \\
\text { Compustat(2019). }\end{array}$ \\
CFO & Cash flows from operating activities (OANCF) divided by total \\
asset (AT). & Annual data from Compustat (2019). \\
Dividend & $\begin{array}{l}\text { Dividend per share (DVPSX) times 100 over stock price (PRCC). } \\
\text { Annual datafrom Compustat (2019). }\end{array}$ \\
ROE & Net income (NI) over book equity (CEQ). Annual data from
\end{tabular}




\section{I||||ICMBF}

3rd International Conference on Advanced Research in

MANAGEMENT, BUSINESS \& FINANCE
MUNICH, GERMANY

29-31 July, 2021

Compustat (2019).

Cash

Cash holdings (CHE) over book assets (AT). Annual data from Compustat (2019).

Post $C O V$ IDt

Dummy variable equals one during the COVID period and zero otherwise. Period from February 24th, 2020 to April 17th 2020 represents the COVID period in our analysis.

Daily price range

first as well

Daily high-low price range of a stock (ASKHI -BIDLO) during the

as the second quarter of 2020, scaled by the midpoint of high and low dailyprices ( ASKHI+ BIDLO)/2. Daily date from CRSP.

The control variables in our study are defined following (Albuquerque et al., 2020 and Tahir \& Ibrahim, 2020).

\section{References}

Abduh, M., (2020). Volatility of Malaysian conventional and Islamic indices: does financial crisis matter? Journal of Islamic Accounting and Business Research.

Acharya, V., and Steffen, S., (2020). Stress tests for banks as liquidity insurers in a time of COVID. VoxEU. org, March 22.

Ahmad, F., Seyyed, F. J. and Ashfaq, H., (2020). Managing a Shariah-compliant capital protected fund through turbulent times. Asian Journal of Management Cases, vol 17, pp. S32-S41.

Al-Khazali, O., Lean, H. H. and Samet, A., (2014). Do Islamic stock indexes outperform conven- tional stock indexes? A stochastic dominance approach. Pacific-Basin Finance 
3rd International Conference on Advanced Research in MANAGEMENT, BUSINESS \& FINANCE
MUNICH, GERMANY

29-31 July, 2021

Journal pp. 28:29-46.

Albuquerque, R. A., Koskinen, Y., Yang, S. and Zhang, C., (2020). Love in the time of COVID-19: The resiliency of environmental and social stocks.

Altarawneh, G., and Lucas, M., (2012). Understanding the dominance of Western accounting and neglect of Islamic accounting in Islamic countries. Journal of Islamic Accounting and BusinessResearch.

Amar, A., Slimane, I. B. and Bellalah, M., (2017). Are Non-Conventional Banks More Resilient thanConventional Ones to Financial Crisis?.

Arouri, M., Ben Ameur, H., Jawadi, N., Jawadi, F. and Louhichi, W., (2013). Are Islamic finance innovations enough for investors to escape from a financial downturn? Further evidence from portfolio simulations. Applied Economics, vol. 45, pp.3412-3420.

Arshad, S., and Rizvi, S. A. R., (2013). The impact of global financial shocks to Islamic indices: speculative influence or fundamental changes? Journal of Islamic Finance 2.

Ashraf, D., Rizwan, M. S. and Ahmad, G., (2020). Islamic Equity Investments and the COVID-19 Pandemic. Available at SSRN 3611898.

Aziz, S., Jalan, A., Matkovskyy, R. and Bouraoui, T., (2020). Does religious philosophy affect investor behaviour in the COVID-19 times: Evidence from herding in (non-) Shariah compliant energy firms. Available at ResearchGate. net .

Bitar, M., Madies, P. and Taramasco, O., (2017). What makes Islamic banks different? A multivariate approach. Economic Systems, vol 41, pp. 215-235.

Bourkhis, K., and Nabi, M. S., (2013). Islamic and conventional banks' soundness during the 2007-2008 financial crisis. Review of Financial economics, vol 22, pp. 68-77. 
3rd International Conference on Advanced Research in MANAGEMENT, BUSINESS \& FINANCE
MUNICH, GERMANY

29-31 July, 2021

Dewandaru, G., Rizvi, S. A. R. Masih, R., Masih, M. and Alhabshi, S. O. (2014). Stock market co-movements: Islamic versus conventional equity indices with multi-timescales analysis. Eco-nomic Systems, vol 38, pp. 553-571.

Erdoğan, S., Gedikli, A. and Cevik E. I., (2020). The effects of the covid-19 pandemic on conventional and Islamic stock markets in Turkey. Bilimname 2020:89-110.

Hammoudeh, S., W. Mensi, Reboredo, J. C. and Nguyen, D. K., (2014). Dynamic dependence of the global Islamic equity index with global conventional equity market indices and risk factors.Pacific-Basin Finance Journal, vol 30, pp. 189-206.

Hasan, M., and Dridi, J., (2011). The effects of the global crisis on Islamic and conventional banks: A comparative study. Journal of International Commerce, Economics and Policy vol. 2, pp.163-200.

Hassan, M. K., Rabbani, M. R. and Ali, M., (2020). Challenges for the Islamic Finance and bankingin post COVID era and the role of Fintech. J. Econ. Coop. Dev. 43.

Ho, C. S. F., Masood, O., Rehman, A. A. and Bellalah, M., (2012). Syariah accounting and compliant screening practices. Qualitative Research in Financial Markets.

Karim, B. A., Lee, W. S., Karim, Z. A. and Jais, M., (2012). The impact of subprime mortgage crisis on Islamic banking and Islamic stock market. Procedia-Social and Behavioral Sciences, vol. 65, pp. 668-673.

Kayed, R. N., and Hassan, M. K. (2011). The global financial crisis and Islamic finance. Thunderbird International Business Review, vol. 53, pp.551-564.

Lang, L., Ofek, E. and Stulz, R., (1996). Leverage, investment, and firm growth. Journal of financialEconomics, vol. 40, pp.3-29. 
3rd International Conference on Advanced Research in MANAGEMENT, BUSINESS \& FINANCE
MUNICH, GERMANY

29-31 July, 2021

Merdad, H., Hassan, M. K. and Alhenawi, Y., (2010). Islamic versus conventional mutual funds performance in Saudi Arabia: a case study. JKAU: Islamic Econ, vol, 23, pp.157193.

Milly, M., and Sultan, J., (2012). Portfolio diversification during financial crisis: Analysis of faith-based investment strategies. building bridges across the financial communities: The global financial crisis, social responsibility, and faith-based finance. Harvard Law School, Islamic finance project pp. 334-352.

Miniaoui, H., Sayani, H. and Chaibi, A., (2015). The impact of financial crisis on Islamic and conven- tional indices of the GCC countries. Journal of Applied Business Research (JABR), vol.31, pp. 357-370.

Mnif, E., Jarboui, A. and Mouakhar, K., (2020). How the cryptocurrency market has performed during COVID 19? A multifractal analysis. Finance research letters, vol. 36, pp. 101-647.

Ramelli, S., and Wagner, A. F., (2020). Feverish stock price reactions to COVID-19. The Review of Corporate Finance Studies, vol. 9, pp. 622-655.

Salisu, A. A., and Sikiru, A. A., (2020). Pandemics and the Asia-Pacific Islamic stocks. Asian Economics Letters, vol 1, pp. 17-413.

Sherif, M., (2020). The impact of Coronavirus (COVID-19) outbreak on faith-based investments: An original analysis. Journal of Behavioral and Experimental Finance 28:100403.

Sukmana, R., and Kolid, M., (2012). Impact of global financial crisis on Islamic and conventional stocks in emerging market: an application of ARCH and GARCH method. Asian Academy of Management Journal of Accounting \& Finance, vol, 31, pp. 357-370. 


\section{MANAGEMENT, BUSINESS \& FINANCE}

\section{MUNICH, GERMANY}

29-31 July, 2021

Tahir, M., and Ibrahim, S., (2020). The performance of Shariah-compliant companies during and after the recession period-evidence from companies listed on the FTSE All World Index. Journal ofIslamic Accounting and Business Research.

Trabelsi, L., Bahloul, S. and Mathlouthi, F., (2020). Performance analysis of Islamic and conven- tional portfolios: The emerging markets case. Borsa Istanbul Review, vol. 20, pp. 48-54.

Yarovaya, L., Elsayed, A. H. and Hammoudeh, S. M., (2020). Searching for Safe Havens during the COVID-19 Pandemic: Determinants of Spillovers between Islamic and Conventional FinancialMarkets. Available at SSRN 3634114. 